\title{
Ellipsis
}

2021

\section{Where Else Does My Mother Go When She Dream Walks?}

Nikki Ummel

Follow this and additional works at: https://scholarworks.uno.edu/ellipsis

\section{Recommended Citation}

Ummel, Nikki (2021) "Where Else Does My Mother Go When She Dream Walks?," Ellipsis: Vol. 46, Article 9.

DOI: https://doi.org/10.46428/ejail.46.09

Available at: https://scholarworks.uno.edu/ellipsis/vol46/iss1/9

This Poetry is brought to you for free and open access by the Department of English and Foreign Languages at ScholarWorks@UNO. It has been accepted for inclusion in Ellipsis by an authorized editor of ScholarWorks@UNO. For more information, please contact scholarworks@uno.edu. 


\section{Vassar Miller Poetry Award \\ Honorable Mention}

\section{Where Else Does My Mother Go When She Dream Walks? \\ By Nikki Ummel}

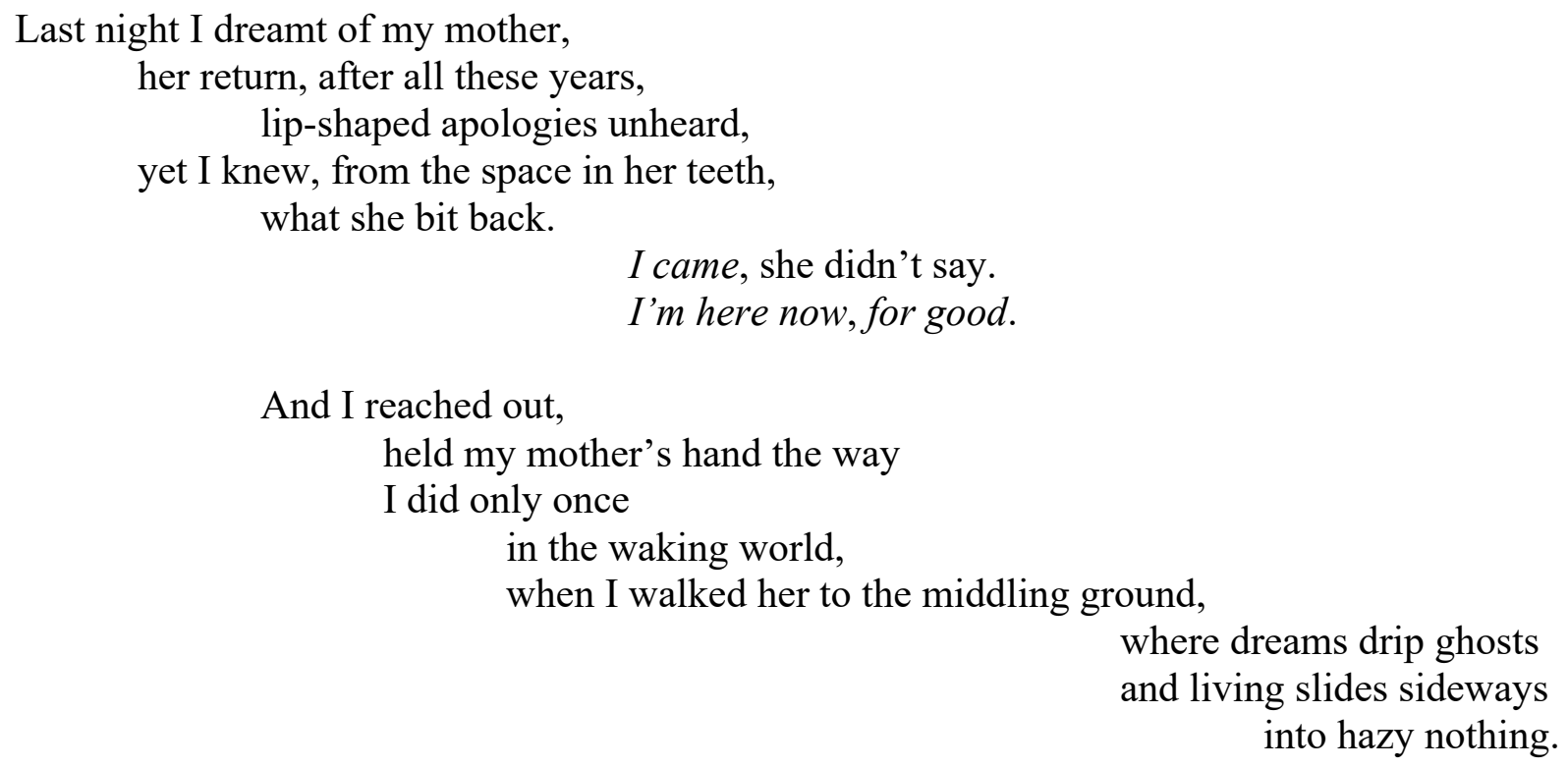

When I woke, mouth open, sticky tears pooling like blood behind my head,

hand grasping the pillow as if

human were an easier concept

at dawn, I strained to hear

her hum from the fireplace, the soot song spilling, begging to take my arm and lead me back to the dream where time ends,

my head in her lap, her hands in my hair, and sleep that brings peace. 